\title{
ANALISIS DAMPAK PENERAPAN KEBIJAKAN BONDED WAREHOUSE (GUDANG BERIKAT) TERHADAP BIAYA LOGISTIK DI PELABUHAN
}

\author{
*Sapit Hidayat dan Habibi Palippui \\ Prodi Manajemen Pelabuhan, Program Diploma Pelayaran, Universitas Hang Tuah Surabaya \\ *shidayat@uht.ac.id
}

\begin{abstract}
Abstrak
Gudang Berikat merupakan tempat menimbun barang impor, dapat disertai 1 (satu) atau lebih kegiatan berupa pengemasan/pengemasan kembali, penyortiran, penggabungan (kitting), pengepakan, penyetelan, pemotongan, atas barang-barang tertentu dalam jangka waktu tertentu untuk dikeluarkan kembali. Dalam Peraturan Menteri Keuanga (PMK) No.155/PMK.04/2019 tentang Gudang Berikat, Kementerian Keuangan menekankan bahwa pengetatan pengawasan ini dilakukan dalam dua bentuk baik dari sisi perpajakan maupun mekanisme pemasukan barang. Kebijakan gudang berikat ini diharapkan mengurangi biaya logistik nasional dengan menurunkan dwelling time di pelabuhan dan mempercepat akses gudang bahan baku ke Industri. Inti dari penelitian ini menganalisis sejauh mana pengaruh yang diperoleh oleh pengguna jasa gudang berikat dari sisi biaya logistik. Perbandingan biaya diperoleh dari survei dengan perusahaan yang sudah memanfaatkan fasilitas gudang berikat.
\end{abstract}

Kata kunci: Gudang Berikat, Biaya Logistik, Dweling Time, Bonded Warehouse.

\begin{abstract}
A bonded warehouse is a place to store imported goods, which can be accompanied by one or more activities in the form of packaging / repacking, sorting, merging (kitting), packing, adjusting, cutting, for certain goods within a certain period to be reissued. In the Minister of Finance Regulation (PMK) No.155 / PMK.04 / 2019 concerning Bonded Warehouses, the Ministry of Finance emphasizes that this tightening of supervision is carried out in two forms, both in terms of taxation and the mechanism for importing goods. This bonded warehouse policy is expected to reduce national logistics costs by reducing dwelling time at ports and accelerating access to raw material warehouses to industry. The essence of this study is to analyze the extent of the influence obtained by users of bonded warehouse services in terms of logistics costs. Cost comparisons are obtained from surveys with companies that have already utilized bonded warehouse facilities.
\end{abstract}

Keywords: Bonded Warehouse, Logistics Costs, Dwelling Time, Bonded Warehouse.

\section{PENDAHULUAN}

Gudang berikat (bonded warehouse) adalah gudang pabean Indonesia yang di dalamnya diberlakukan ketentuan khusus terhadap barang yang dimasukkan dari luar pabean atau dari dalam lingkup pabean di Indonesia lainnya tanpa dikenakan pungutan bea cukai dan atau pungutan negara lainnya sampai barang tersebut dikeluarkan untuk tujuan impor, ekspor, dan re-ekspor. Gudang berikat merupakan fasilitas yang dikembangkan guna menunjang industri dalam negeri dan mendorong terciptanya hubungan perdangan internasional dalam lingkup pelabuhan dengan menawarkan fasilitas berupa penangguhan bea masuk, tidak dipungut ppn dan ppnb serta pembebasan cukai. Melalui gudang berikat, ada fleksibilitas yang ditawarkan mulai dari pemasukan dan pengeluaran barang selain itu kegiatan sederhana yang dapat dilakukan, status kepemilikan barang, serta fasilitas perpajakan dan kepabeanan yang dekat dari akses pelabuhan. Kegiatan yang dapat dilakukan di dalam gudang adalah pengemasan ulang dan labeling. Gudang berikat bisa diatrikan sebagai gudang logistik multifungsi yang bea masuk dan pajak impornya ditunda pembayarannya, sehingga dapat 
memangkas biaya tunggu atau Dwelling Time di Pelabuhan dengan menghilangkan tahap custom cleareance. Logistic Performance Indeks (LPI) memberikan gambaran kinerja logistik yaitu prosedur kepabeanan, biaya logistik, kualitas infrastruktur dalam melacak pengiriman, ketepatan waktu sampai ke tujuan dan kompetensi industri logistik nasional [1]. Berdasarkan informasi dari LPI, menurunnya peringkat Indonesia dalam survei LPI 2016 perlu mendapatkan perhatian lebih karena lebih dari 100 negara yang disurvei, Indonesia berada di peringkat ke-63, mengalami penurunan jika dibandingkan survey pada tahun 2014.

Salah satu PLB yang sudah mulai diterapkan di Indonesia yaitu komoditi kapas sebagai bahan baku untuk mendukung Industri Tekstil dan Produk Tekstil (TPT). Pada tahun 2010 hingga 2014 produksi impor kapas ke dalam negeri mengalami peningkatan 9,25\%, dengan impor pada tahun 2014 sebesar 708.793 Ton. Panjangnya rantai impor kapas membuat harga bahan baku tekstil menjadi tinggi ketika sampai pengguna akhir. Perlu dilakukan efisiensi pengadaan kapas dari negara pengimpor langsung ke gudang di Indonesia agar jarak antara pelaku usaha menjadi dekat dan efektif.

Secara umum gudang berikat meminimalkan jarak antara pelaku usaha dengan bahan baku di dalam negeri, sehingga dapat menekan harga bahan baku dan menurunkan harga produksi [2]. Pelaku usaha juga akan diuntungkan dengan memperoleh bahan baku yang lebih murah, mobilisasi lebih cepat, sehingga hasil produksinya dapat bersaing baik di pasar dalam negeri maupun pasar internasional (Peraturan Pemerintah No.85 Tahun 2015). Lokasi gudang berikat dibangun di dekat sentra industri tertentu sehingga mempermudah arus barang dari pusat logistik berikat ke pabrik produksi [3]. Tujuan utama penerapan PLB adalah mengefisiensikan rantai pasok yaitu dengan mendekatkan bahan baku industri tekstil misalnya kapas. Efisiensi yang dimaksudkan yaitu tempat, waktu, dan jarak gudang. Berbagai gudang berikat yang tersebar di Indonesia ditampilkan pada tabel dan gambar sebagai berikut.

Tabel 1. Gudang berikat [3]

\begin{tabular}{lll}
\hline No. & Nama Gudang & Lokasi \\
\hline 1 & PT. Cipta Krida Bahari & Cakung \\
2 & PT. Agility Cikarang & Cikarang \\
3 & PT. Khrisna Cargo & Bali \\
4 & PT. Kamadjaya Logistics & Bekasi \\
5 & PT. Petrosea Tbk & Balikpapan \\
6 & PT. Pelabuhan Penajam Buana & Balikpapan \\
7 & PT. Dunia Express Transindo & Sunter \\
8 & PT. Toyota Motor Manufacturing & Karawang \\
9 & PT. Vopak Terminal & Merak \\
10 & PT. Dahana & Subang \\
11 & PT. Gerbang Teknologi Jababeka & Cikarang \\
\hline
\end{tabular}

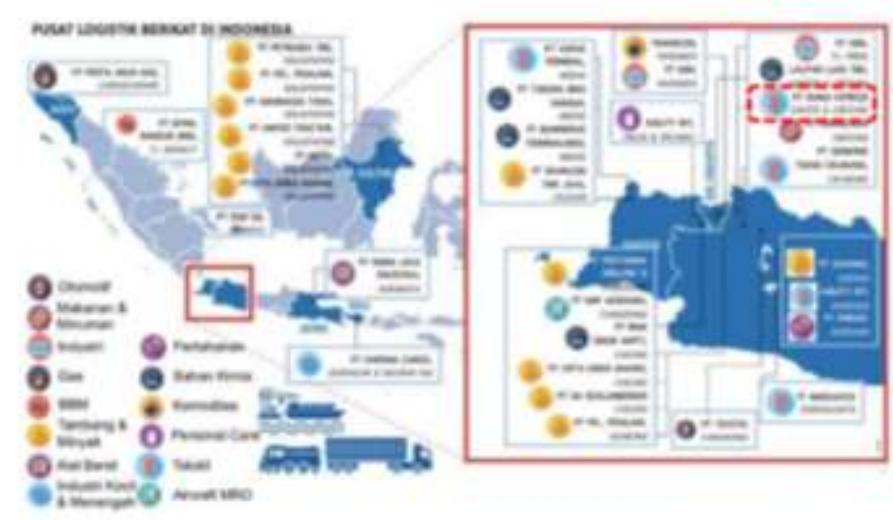

Gambar 1. Peta sebaran Gudang Berikat di Indonesia [3]

\section{IMPOR}

Kegiatan perdagangan internasional dengan memasukkan barang ke wilayah pabean Indonesia yang dilakukan perorangan atau perusahaan yang bergerak di bidang ekspor impor dengan mematuhi ketentuan peraturan perundang-undangan yang berlaku yang dikenakan bea masuk. Menurut Direktorat Jenderal Bea dan Cukai copyright is published under Lisensi Creative Commons Atribusi 4.0 Internasional. 
adalah kegiatan memasukkan barang dari daerah kepabeanan suatu negara. Daerah pabean adalah wilayah Republik Indonesia yang meliputi wilayah darat, perairan, dan ruang udara di atasnya, serta tempat - tempat tertentu di Zona Ekonomi Eksklusif dan landas kontingen yang di dalamnya berlaku Undang-Undang [4].

Dasar hukum peraturan mengenai Tatalaksana Impor diatur dalam Keputusan Direktur Jendral Bea dan Cukai Nomor KEP-07/BC/2003. Tentang petunjuk pelaksanaan Tatalaksana Kepabeanan di bidang impor dan Keputusan Menteri Keuangan Nomor 453/KMK.04/2002 tentang Tatalaksana Kepabeanan di bidang impor. Komoditi yang dimasukkan ke wilayah pabean, yang dibawa dari luar wilayah pabean dikenakan bea masuk kecuali dibebaskan atau diberikan pembebasan.

Sedangkan sesuatu yang berhubungan dengan pengawasan atau lalu lintas barang yang masuk atau keluar daerah pabean dan pemungutan bea masuk disebut dengan kepabeanan. Untuk tatalaksana kepabeanan di bidang impor juga terdapat dokumen yang harus dilengkapi seperti pada tabel berikut [5].

Tabel 2. Dokumen Kepabeanan

\begin{tabular}{ll}
\hline Kode & Keterangan \\
\hline BC 1.0 & Pemberitahuan rencana kedatangan sarana pengangkut. \\
BC 1.1 & Pemberitahuan barang kargo/niaga yang diangkut dalam sarana pengangkut. \\
BC 1.2 & Pemberitahuan barang impor yang diangkut lanjut. \\
BC 1.3 & Pemberitahuan pengangkutan barang asal daerah pabean dari satu tempat ke tempat lain \\
& melalui luar daerah pabean. \\
BC 2.0 & Pemberitahuan Impor Barang. \\
BC 2.1 & Pemberitahuan Impor Barang Tertentu. \\
BC 2.2 & Pemberitahuan Impor Barang penumpang/awak sarana pengangkut. \\
BC 2.3 & Pemberitahuan pengangkutan barang impor/ekspor dari satu tempat ke tempat lain dalam \\
& pengawasan pabean. \\
BC 2.4 & Pengeluaran barang impor dari TPB ke DPIL. \\
BC 2.5 & Pemberitahuan pengeluaran barang dari tempat penimbunan berikat. \\
BC 3.0 & Pemberitahuan Ekspor Barang \\
BC 4.0 & Pemberitahuan pemasukan barang asal daerah pabean ke KawasanBerikat \\
\hline
\end{tabular}

Proses impor merupakan penetapan Jalur Pelayanan Impor, Pengeluaran Barang Impor, Pasca Persetujuan, dan Pengeluaran Barang. Adapun proses atau prosedur impor di Indonesia ditampilkan pada gambar berikut.

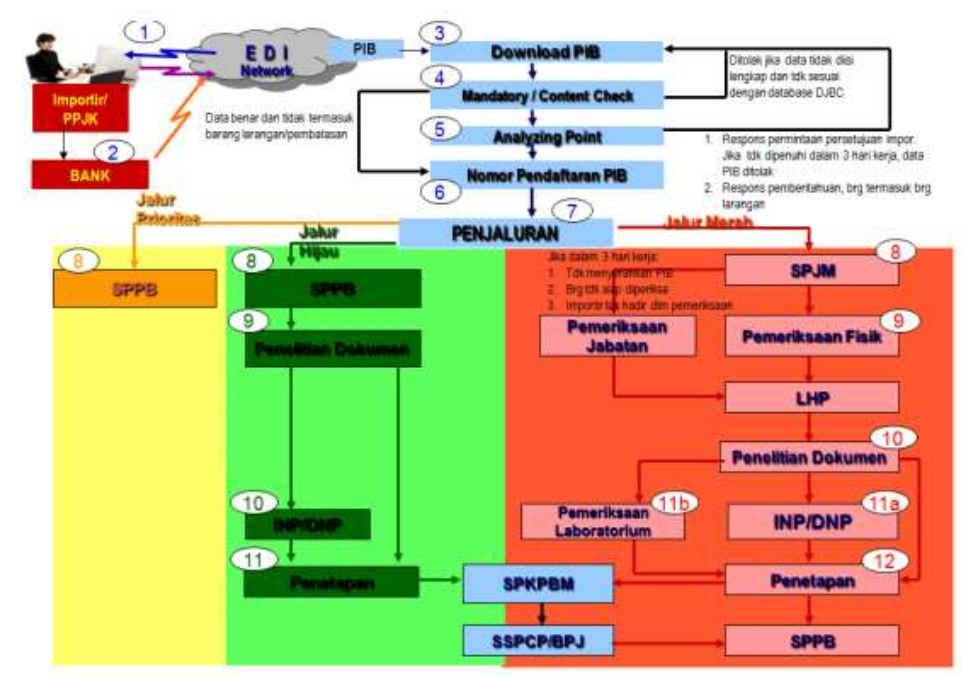

Gambar 2. Alur impor Indonesia [6]

Berdasarkan Gambar 2 barang impor yang telah diajukan PIB dilakukan pemeriksaan pabean secara selektif. Dalam rangka pemeriksaan pabean secara selektif inilah ditetapkan jalur pengeluaran barang, yaitu [7]

a. Jalur Merah Proses pelayanan dan pengawasan pengeluaran barang impor dengan dilakukan pemeriksaan fisik, dan dilakukan penelitian dokumen sebelum diterbitkannya Surat Persetujuan Pengeluaran Barang (SPPB).

b. Jalur Hijau Proses pelayanan dan pengawasan pengeluaran barang impor dengan tidak dilakukan copyright is published under Lisensi Creative Commons Atribusi 4.0 Internasional. 
pemeriksaan fisik, tetapi dilakukan penelitian dokumen setelah diterbitkannya Surat Persetujuan Pengeluaran Barang (SPPB).

c Jalur Kuning Proses pelayanan dan pengawasan pengeluaran barang impor dengan tidak dilakukan pemeriksaan fisik, tetapi dilakukan penelitian dokumen sebelum diterbitkannya Surat Persetujuan Pengeluaran Barang (SPPB).

d. Jalur Prioritas Proses pelayanan dan pengawasan pengeluaran barang impor yang tidak dilakukan pemeriksaan fisik dan penelitian dokumen, setelah ada penetapan dari Pemerintah terhadap importir jalur prioritas tersebut.

\section{BIAYA LOGISTIK}

Biaya logistik salah satu alat untuk mengukur kinerja logistik nasional. Pembagian komponen biaya logistik penting untuk mempermudah pencapaian kinerja logistik yang efisien. Ditingkat operasional, indikator biaya logistik dapat digunakan untuk menekan biaya operasional dan meningkatkan pelayanan logistik yang kemudian dapat meningkatkan arus barang menjadi lebih cepat dan lebih murah sehingga dapat meningkatkan daya saing usaha. Komponen biaya logistik ditampilkan pada gambar grafik berikut ini:

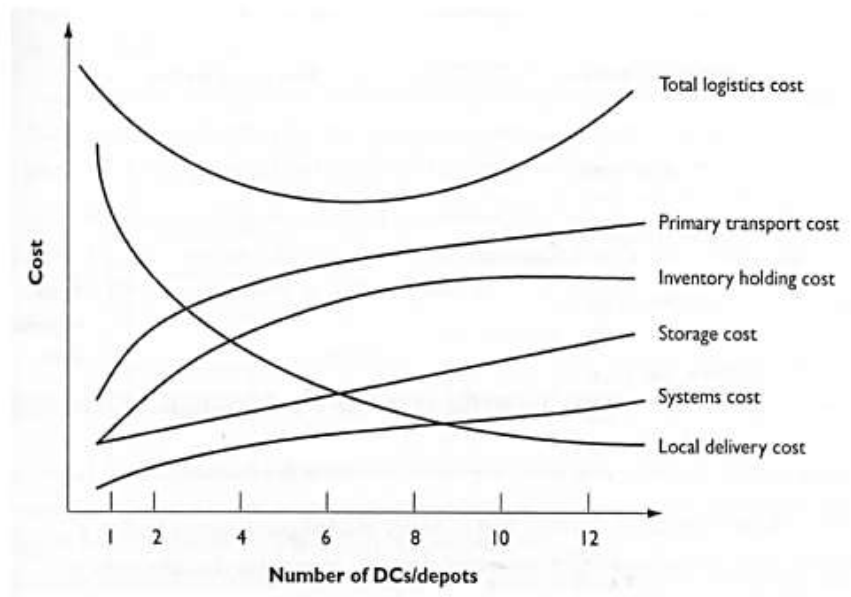

Gambar 3. Komponen Biaya Logistik [7]

Dari gambar grafik di atas storage cost (biaya penimbunan/pelabuhan) tidak mengalami strim line, biaya akan terus meningkat seiring dengan bertambahnya waktu sewa. Besar tidaknya keuntungan dari hasil produksi tidak mempengaruhi biaya sewa gudang. Dengan kata lain sewa gudang akan terus ada meskipun proses produksi tidak berlangsung. Hal ini menandakan bahwa biaya tersebut tidak dipengaruhi faktor luar sehingga menjadi biaya konstan yang akan terus dikeluarkan. Hanya saja Biaya penyimpanan barang di gudang, dipengaruhi tipe penyimpanan dan penanganan barang yang digunakan, jumlah dan volume barang yang disimpan serta ukuran dan lokasi gudang itu sendiri.

\section{KOMODITI GANDUM INDONESIA}

Gandum salah satu alternatif makanan pokok di beberapa daerah di Indonesia seperti Maluku, Nusa Tenggara, dan Papua. Di luar itu, gandum banyak dimanfaatkan dalam bidang bisnis dan industri kuliner dan katering, dan akan terus bertambah seiring semakin banyaknya inovasi akan variasi makanan. Penggunaan gandum sebagai terigu paling dominan ada pada bahan baku mie instan dan roti karena keduanya merupakan makanan favorit masyarakat Indonesia yang terus meningkat nilai permintaannya.

Sementara itu, laporan dari Asosiasi Produsen Tepung Terigu Indonesia (Aptindo) menunjukkan bahwa impor gandum dari Juli 2015 sampai Mei 2016 telah mencapai total 8,2 juta ton. Sedangkan sepanjang 2016 mencapai 8,71 juta ton. Impor gandum tahun ini ditaksir meningkat antara 5-6 persen hingga 8,79 juta ton.

Menurut data indopress, kebutuhan gandum Indonesia telah menyalip Mesir, penguasa impor gandum sedunia. Pada 2013, Indonesia hanya menyedot 7,39 juta ton gandum berikut produk turunannya sementara Mesir 10,15 juta metrik ton. Namun, pada 2018, menurut data Kementerian Pertanian Amerika, Indonesia mengimpor 
12,5 juta metrik ton, melampaui Mesir yang mencatat impor 12 juta metrik ton. Seperti ditampilkan pda graffikberikut.

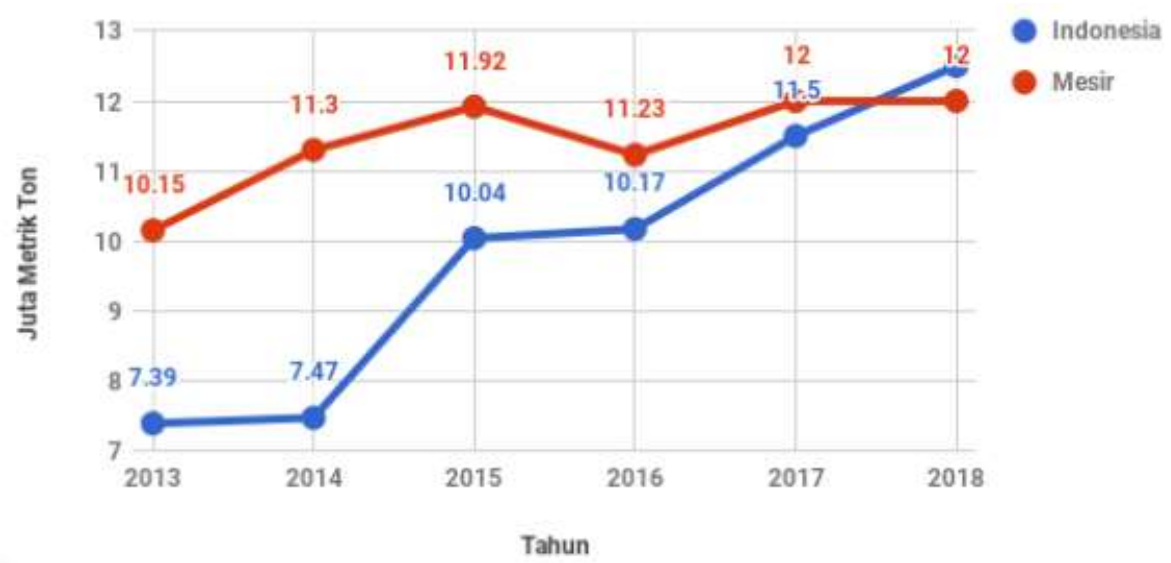

Gambar 4. Gerafik kebutuhan gandum Indonesia dan Mesir [3]

Sementara itu, demand gandum nasional di satu sisi terus meningkat. Sepanjang tahun 2011, ada impor 6,3 juta ton gandum dengan nilai US\$2,5 miliar. Pelaku impor adalah Bogasari Flour Mills (Bogasari) anak usaha PT Indofood Sukses Makmur Tbk yang mengimpor gandum rata-rata perbulannya sebesar 300 ribu ton. Jumlah ini akan terus meningkat karena besarnya permintaan produk gandum di Tanah Air. Impor gandum biasanya dilakukan dari Australia, Kanada, Amerika Serikat, China, dan beberapa negara Eropa Timur. Tindakan impor ini semakin dipermudah dan dibuka lebar karena gandum termasuk salah satu produk impor selain kapas yang dibebaskan dari tarif pajak masuk alias $0 \%$.

\section{STUDI KASUS IMPOR TEPUNG GANDUM}

Pada sebelum pengoperasian gudang berikat untuk pengiriman impor tepung gabdum dilakukan dengan menggunakan petikemas, dimana pengusaha industri Indonesia yang membutuhkan bahan baku tepung gandum masih harus menunggu melalui proses yang panjang dikarenakan Negara Importir terletak jauh dari Indonesia yang mengharuskan melakukan transhipment ataupun harus menggunakan gudang penyimpanan yang berada di Negara Australia. Berikut gambaran Sebelum dan seudah penerapan Gudang berikat.
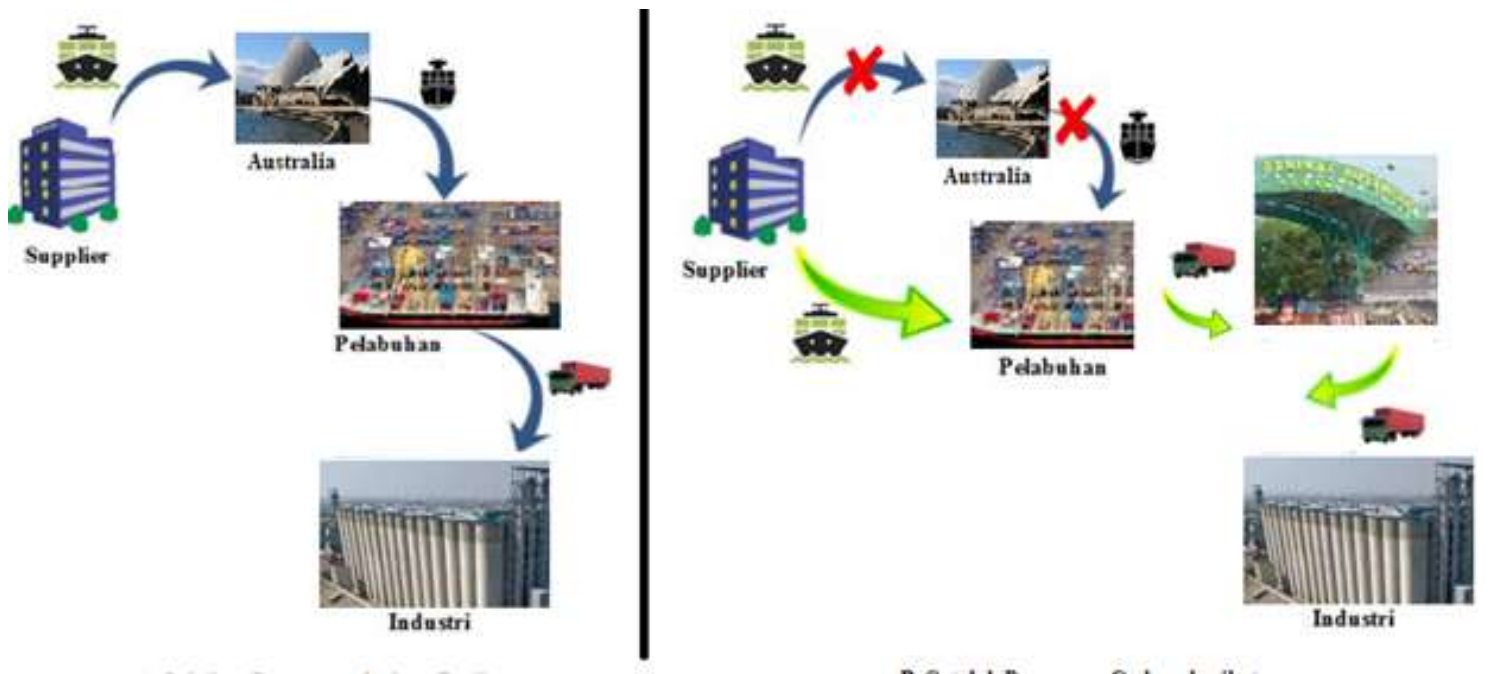

A. Sebelum Penerapan Gudang Berikat

B. Setelah Peaerapan Gudang berikat

Gambar 5. Perbedaan alur sebelum dan sesudah penerapan gudang berikat

Berdasarkan gambar di atas dapat dilihat bahwa ada penambahan dan pengurangan alur logistik. Adanya perubahan tersebut maka besar kemungkinan akan ada perbedaan biaya logistik di pelabuhan. Penelitian ini akan menganalisis besar perbedaan baiya sebelum dan sesudah penerapan gudang berikat. 
Untuk memenuhi demand PT Indofood Sukses Makmur Tbk. dalam satu tahun 2011 sebesar 300.000 ton/bulan atau sekitar 3.600.000 ton/tahun, dilakukan perhitungan kebutuhan kontainer untuk kondisi sebelum ada kebijakan gudang berikat dengan asumsi-asumsi ditunjukkan pada tabel berikut.

Tabel 4. Asumsi kebutuhan kontainer

\begin{tabular}{|c|c|}
\hline Demand & 3.600.000 Ton \\
\hline \multicolumn{2}{|l|}{ Asumsi } \\
\hline $20{ }^{\prime}$ & $25 \%$ \\
\hline $40^{\prime}$ & $75 \%$ \\
\hline Load Factor Kapal & $90 \%$ \\
\hline \multicolumn{2}{|l|}{ Demand dalam Petikemas } \\
\hline $20^{\prime}$ & 900.000 Ton \\
\hline $40^{\prime}$ & 2.700.000 Ton \\
\hline
\end{tabular}

\section{BIAYA PENUMPUKAN}

\subsection{Biaya Gudang di Australia}

Dari proses pengiriman impor gandum dari negara asal kapal melakukan transhipment dan biasanya melakukan penumpukan selama satu bulan di gudang konsolidasi di Australia, terdiri dari biaya penumpukan, biaya handling, dan biaya custom clearance. Dari hasil penelitian di lapangan sebelum adanya gudang berikat total biaya pelabuhan didapatkan sebagai berikut.

Tabel 5. Biaya penumpukan di Australia [3]

\begin{tabular}{llll}
\hline Biaya & Satuan & $20^{\prime}$ & $40^{\prime}$ \\
\hline Covered Storage & Rp/tahun & $108,894,126,085$ & $657,740,759,040$ \\
Handling & $\mathrm{Rp} /$ tahun & $23,096,678,217$ & $132,726,266,879$ \\
Custom & $\mathrm{Rp} /$ tahun & $8,310,154,357$ & $50,256,307,202$ \\
Clearance & & & \\
Rp/tahun & & $140,300,958,658$ & $840,723,333,121$ \\
Total & & $981,024,291,779$ & \\
\hline
\end{tabular}

Dari keseluruhan kegiatan yang dilakukan di Gudang didapatkan Biaya Total 981,024,291,779 Rp/tahun dan dengan biaya per unit $\operatorname{Rp} 272,507 /$ ton.

\subsection{Biaya Pelabuhan di Australia}

Biaya pelabuhan selain biaya bongkar muat dari kapal menuju dermaga ataupun sebaliknya. Biaya pelabuhan didapatkan dari biaya penumpukan di Countainer Yeard, biaya Lo-Lo, biaya recovery, dll. Dari hasil penelitian di lapangan sebelum adanya Gudang berikat total biaya pelabuhan didapatkan sebagai berikut.

Tabel 6. Biaya Pelabuhan di Australia [3]

\begin{tabular}{llll}
\hline Biaya & Satuan & $20^{\prime}$ & $40^{\prime}$ \\
\hline Port Storage & $\mathrm{Rp} /$ tahun & $6,190,200,000$ & $42,854,400,000$ \\
Lo-Lo Cost & $\mathrm{R} /$ tahun & $2,730,176,471$ & $14,179,764,706$ \\
Lainnya & $\mathrm{Rp} /$ tahun & $2,836,038,504$ & $15,023,020,147$ \\
& Rp/tahun & $11,756,414,974$ & $72,057,184,853$ \\
& Total & $83,813,599,827$ & \\
\hline
\end{tabular}

Dari keseluruhan biaya pelabuhan didapatkan Biaya Total 83,813,599,827 Rp/tahun, dan dengan biaya per unit $\operatorname{Rp} 23,282 /$ ton.

\subsection{Biaya Gudang Berikat di Indnesia (Tanjung Priok)}

Yang termasuk dalam biaya penumpukan yaitu biaya pelabuhan selain biaya bongkar muat dari kapal menuju copyright is published under Lisensi Creative Commons Atribusi 4.0 Internasional. 
dermaga ataupun sebaliknya. Biaya pelabuhan didapatkan dari biaya penumpukan di CY, biaya Lo-Lo, biaya recovery, dll. Seperti ditampilkan pada tabel berikut.

Tabel 7. Biaya Pelabuhan di Indonesia (Tanjung Priok)

\begin{tabular}{lll}
\hline Komponen biaya & $20^{\prime}$ & $40^{\prime}$ \\
\hline Biaya & Rp.244,800 & Rp.489,600 \\
Penumpukan & Rp.21,600 & Rp.32,400 \\
LoLo & Rp.193,619 & Rp.263,826 \\
Biaya Lain-Lain & Rp.900,000 & Rp.2,700,000 \\
Jumlah Muatan & Rp.220,320,000,000 & Rp. $1,321,920,000,000$ \\
Biaya & Rp.19,440,000,000 & Rp. $87,480,000,000$ \\
Penumpukan & Rp. $174,257,100,000$ & Rp. $712,330,200,000$ \\
LoLo & Rp.414,017,100,000 & Rp.2,121,730,200,000 \\
Biaya Lain-Lain & Jumlah & \\
Total & $2,535,747,300,000$ & \\
\hline
\end{tabular}

Berdasarkan hasil perhitungan biaya pelabuhan, didapat masing-masing Biaya Total dan biaya per TEUs-nya seperti pada tabel diatas. Maka dapat diperoleh Biaya Total Pelabuhan dalam satu tahun yaitu sebesar Rp 2,535,747,300,000 untuk memenuhi seluruh permintaan impor kapas sebanyak 3.600.000 ton/tahun. Dengan mengetahui Biaya Total impor dan permintaan impor per tahun yang ditangani PLB PT Dunex, maka diperoleh biaya per Unit sebesar Rp 704,374/ton.

Tabel 8. Biaya Warehouse

\begin{tabular}{lll}
\hline Biaya & $20^{\prime}$ & $40^{\prime}$ \\
\hline Handling 1st cont & Rp.475,000 & Rp.500,000 \\
Quaranteen & Rp.150,000 & Rp. 150,000 \\
Covered Warehouse & Rp.300,000 & Rp.300,000 \\
Jumlah Muatan & Rp.900,000 & Rp.2,700,000 \\
Handling 1st cont & Rp.427,500,000,000 & Rp. $1,350,000,000,000$ \\
Quaranteen & Rp.135,000,000,000 & Rp.405,000,000,000 \\
Covered Warehouse & Rp.270,000,000,000 Rp.810,000,000,000 \\
Biaya Storage & Rp.832,500,000,000 Rp.2,565,000,000,000 \\
Total & Rp.3,397,500,000,000 \\
\hline
\end{tabular}

Berdasarkan hasil perhitungan biaya Gudang berikat, didapat masing-masing Biaya Total dan biaya per TEUsnya seperti pada tabel di atas. Maka dapat diperoleh Biaya Total Gudang berikat dalam satu tahun yaitu sebesar Rp.3,397,500,000,000 untuk memenuhi seluruh permintaan impor kapas sebanyak 3.600.000 ton/tahun. Dengan mengetahui Biaya Total Impor dan permintaan impor per tahun yang ditangani PLB PT. Dunex, maka diperoleh biaya per Unit sebesar Rp 943.750/ton.

\subsection{Perbandingan Biaya}

Setalah dilakukan perhitungan di atas, diketahui biaya per unit pada masing-masing komponen biaya penumpukan pelabuhan setelah diberlakukannya kebijakan gudang berikat di Indonesia. Maka dilakukan perbandingan Biaya Total antara sebelum dan setalah adanya gudang berikat dapat dilihat sebagai berikut.

Tabel 9. Perbandingan Biaya

\begin{tabular}{llll}
\hline Biaya & Tidak Melalui Gudang Berikat & Melalui Gudang Berikat & Satuan \\
\hline Biaya Warehouse Australia & $981,024,291,779$ & & Rp/tahun \\
Biaya Pelabuhan & $3,397,500,000,000$ & $3,397,500,000,000$ & Rp/tahun \\
Biaya Warehouse Indonesia & $2,535,747,300,000$ & $2,535,747,300,000$ & Rp/tahun \\
Jumlah Biaya & $6,914,271,591,779$ & $5,933,247,300,000$ & Rp/tahun \\
Selisih Biaya & & $981,024,291,779$ & Rp/tahun \\
\hline
\end{tabular}




\section{KESIMPULAN}

Dari analisa total cost demand tepung gandum dari Australia ke Indonesia dengan mempertmbangkan kebijakan gudang berikat maka dapat disimpulkan bahwa terdapat perbedaan biaya yang dikeluarkan saat melalui gudang berikat sebesar Rp. 981,024,291,779/tahun. Dengan kata lain, bisa menghemat pengeluaran sekitar Rp.981,024,291,779/tahun.

\section{DAFTAR PUSTAKA}

[1] Nur, H. I. (2014). Kajian Usulan Kebijakan Pendulum Nusantara: Tinjauan Sektor Pelayaran dan Kepelabuhanan. Surabaya: Jurusan Transportasi Laut ITS.

[2] Ade, S.N., Hang Tuah dan Ofyar. 1999. Analisis Kebutuhan Interaksi Tata Guna Lahan dan Transportasi Studi Kasus Kotamadya Bandung. Bandung.

[3] Cikarang, D. J. (2016, September 28). Dipetik February 2, 2017, dari http://beacukaicikarang.net/sekilastentang-pusat-logistik-berikat-plb/

[4] Dunn, W. N. (2003). Pengantar Analisis Kebijakan Publik (Kedua ed.). Yogyakarta: Gadjah Mada Iniversity Press

[5] Dunn, W. N. (2008). Public Policy Analysis: An Introduction (4th Edition ed.). Englewood Cliffs: Prentice hall.

[6] Kementerian Perhubungan Republik Indonesia. (2015). Peraturan Pemerintah Nomor 11 Tahun 2015 Tentang Jenis dan Tarif atas Jenis Penerimaan Negara Bukan Pajak yang berlaku pada Kementrian Perhubungan. Jakarta: Kementerian Perhubungan Republik Indonesia.

[7] Suyono, R. (2007). Shipping - Pengangkutan Intermodal Ekspor Impor Melalui Laut - Edisi Keempat. Jakarta: PPM. 